\title{
SİKLİN BAĞIMLI KİNAZ 4/6 VE İNHİBİTÖRLERİ
}

\author{
CYCLIN DEPENDENT KINASE 4/6 AND INHIBITORS
}

\section{Gülnur ARSLAN ${ }^{1 *}$ (D) Tijen ÖNKOL ${ }^{2}$ (D) , Azime Berna ÖZÇELİK ${ }^{2}$}

${ }^{1}$ Süleyman Demirel Üniversitesi, Eczacılık Fakültesi, Farmasötik Kimya Anabilim Dalı, 32000, Isparta, Türkiye

${ }^{2}$ Gazi Üniveristesi, Eczacılık Fakültesi, Farmasötik Kimya Anabilim Dalı, 06330, Ankara, Türkiye

\section{$\ddot{\mathbf{O Z Z}}$}

Amaç: Kanser; ülkemizde ve dünyada öldürücülüğü yüksek olarak karşımıza çıkan ciddi sağlık sorunlarından biridir. İkinci sıklıkta görülen kanser türü olan meme kanseri kadınlarda en fazla ölüm nedenidir. Kanser hücresinin oluşum mekanizmalarının aydınlatılmasıyla, ilaç tedavilerinde bir çok yenilikçi yaklaşım keşfedilmiştir. Yenilikçi yaklaşımlardan biri de siklin bağımlı kinaz 4/6 inhibisyonudur. Bu derlemede siklin bă̆ımlı kinaz 4/6 hakkında genel bilgiler verilerek, inhibitörlerinin avantaj ve dezantajları üzerinde durulmuştur.

Sonuç ve Tartışma: Östrojen reseptörü pozitif ve insan epidermal büyüme faktör reseptörü 2 negatif meme kanserlerinde, endokrin tedavilere direncin gelişmesi tedavi sürecini klsitlayan bir unsurdur. Retinoblastoma proteini pozitif meme kanserlerinde endokrin direncin üstesinden gelmek ve kanserli hücrenin mitoz kontrol noktasında durdurulması hedeflenerek siklin bă̆ımlı kinaz 4/6 inhibisyon yolă̆ keşfedilmiştir. Siklin bă̆ımlı kinaz 4 / 6 inhibitörlerinin endokrin tedaviyle kombinasyonuyla kanser terapisinde ümit verici sonuçlar elde edilmiştir.

Anahtar Kelimeler: Antitümör ajan, kanser terapisi, meme kanseri, siklin bă̆ımlı kinaz 4/6 inhibitörleri

\section{ABSTRACT}

Objective: The cancer is one of the serious health problems with high lethality in our country and also in the world. Breast cancer, the second most common type of cancer, is the most common of death in woman. Many innovative approaches have been discovered in drug treatments by elucidating the mechanisms of cancer cell formation. One of the innovative approaches is inhibition of cyclin-dependent kinase 4/6. In this review, general information about cyclin-dependent kinase 4/6 is given and the advantages and disadvantages of its inhibitors are emphasized.

Result and Discussion: The development of resistance to endocrine therapies is a factor limiting the treatment process in estrogen receptor positive and human epidermal growth factor receptor 2 negative breast cancers. Cyclin-dependent kinase 4/6 inhibition pathway was discovered in retinoblastoma protein-positive breast cancers by targeting to overcome the endocrine resistance and arrest the cancerous cell at the mitosis

\footnotetext{
* Sorumlu Yazar / Corresponding Author: Gülnur Arslan e-posta / e-mail: gulnurarslan@ @ sdu.edu.tr, Tel./ Phone: +905068042093
} 
checkpoint. Promising results in cancer therapy have been obtained with the combination of cyclin-dependent kinase 4/6 inhibitors with endocrine therapy.

Keywords: Antitumor agent, cancer therapy, breast cancer, cyclin-dependent kinase 4/6 inhibitors

\section{GíRIŞ}

Siklinler hücre döngüsü düzenleyicileri arasında en önemli protein ailelerindendir. Siklinlerin insanlarda ve diğer ökaryotların çoğunda bulunan dört temel tip vardır: G1 siklinler, G1 / S siklinler, S siklinler ve M siklinler [1].

Her siklin, hücre döngüsündeki (Şekil 1) belirli bir faz, geçiş veya fazlar dizisi ile ilişkilidir ve bu fazın olaylarını yönlendirmektedir. Her bir fazda ilgili siklinlerin konsantrasyonu değişir ve döngü boyunca siklin sentezi ve yıkımı devam etmektedir [2].

Sikline bağımlı kinazlar (CDK), hücre döngüsü ilerlemesi ve RNA transkripsiyonunun kritik düzenleyicileridir. Genetik ve epigenetik olaylar, insan kanserinde hücre döngüsü CDK'larının aşırı aktivitesine neden olur ve bunların inhibisyonu, hem hücre döngüsü durmasına hem de apoptoza yol açar [3].

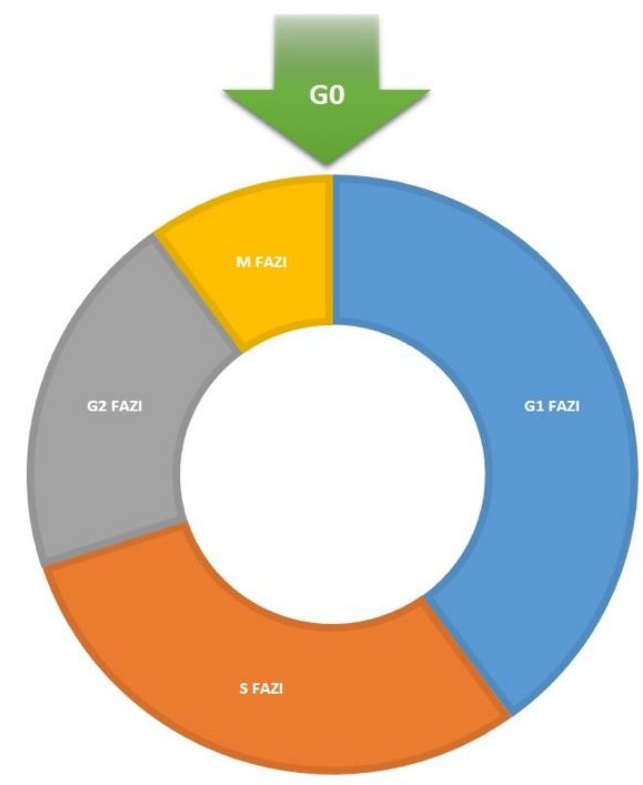

Şekil 1. Hücre döngüsü

Siklin bağımlı kinaz (CDK), hücre döngüsü ilerlemesi, transkripsiyon ve nöronal fonksiyonun kontrolünde rol oynayan memeli heterodimerik serin / treonin kinaz ailesinin katalitik alt birimleridir. CDK'ın katalitik aktivitesi, düzenleyici bir alt birimin bağlanmasını gerektirdiğinden, CDK terimi genellikle aktif heterodimerik kompleks için kullanılır. CDK'yı hücre döngüsü sırasında sentezlenen siklinler aktivite eder ve CDK aktivasyonu tamamlanınca siklin seviyesi hızla azalır (Şekil 2) [4]. 


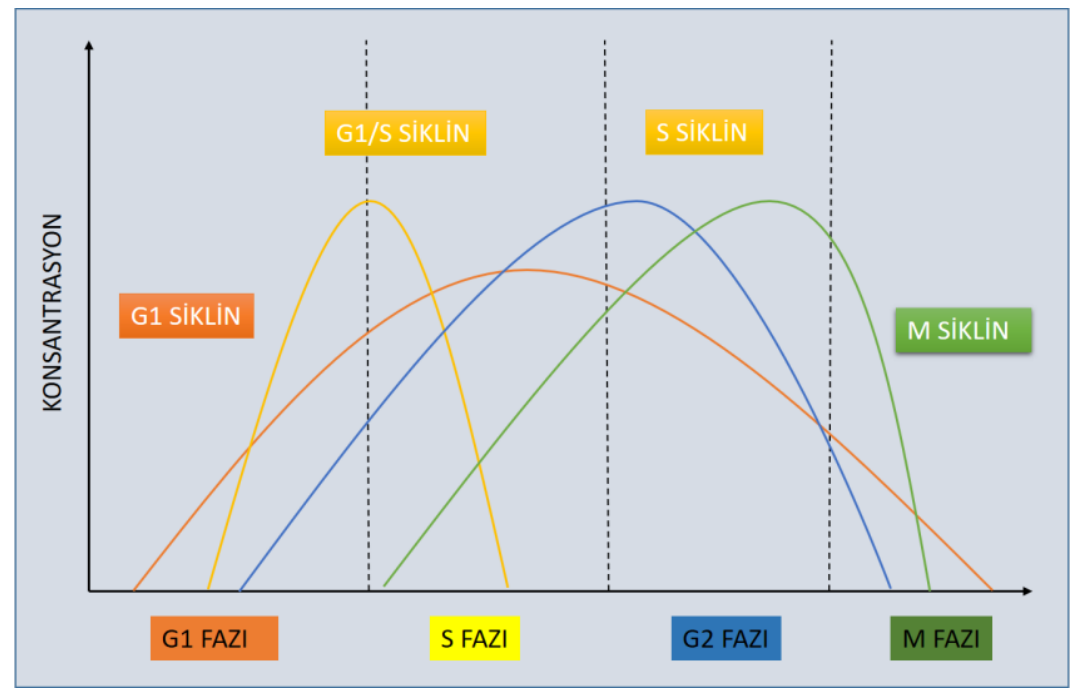

Şekil 2. Hücre döngüsünde siklin seviyeleri

G1, hücrelerin bölünmesinde bir sonraki aşamaya (S) güvenli şekilde ilerlemek için gerekli olan tüm bilgilerin edinildiği hücre döngüsünün ilk aşamasıdır. Hücreler, aktif olarak çoğalıyorlarsa (M / G1 geçişi) sitokinezi tamamladıktan sonra veya daha önce döngüden çıkmışlarsa (G0 / G1 geçişi) G0 olarak bilinen durgun bir durumdan G1'e girerler. Hücre kültürü deneylerinde, mitojenik stimülasyondan birkaç saat sonra hücrelerin mitojen bağımsız hale geldiği gösterilmiştir. Ayrıca mitojenlerin uzaklaştırılması, G0'a dönmelerini sağlar. Mitojen bağımlılığından mitojen bağımsızlığına bu kritik geçiş, kısıtlama (R) noktası olarak adlandırılmaktadır. Genellikle, bu geçiş G1 fazını erken ve geç G1'e bölmek için kullanılır. Her durumda, R noktası bir 'geri dönüşü olmayan noktayı' temsil eder, bundan sonra hücreler yeni replikasyon döngüsüne geçiş yapar. $\mathrm{R}$ noktasından geçişi düzenleyen mekanizmaların düzgün kontrolü, normal hücre proliferasyon seviyelerini korumak hiperplastik veya neoplastik büyümeyi önlemek için gereklidir [5].

\section{Hücre Döngüsünde CDK4 / 6 ve Diğer CDK'ların Rolü}

Hücre döngüsü düzenlemesinde $\mathrm{CDK} 1, \mathrm{CDK} 2, \mathrm{CDK} 3, \mathrm{CDK} 4$ ve CDK6'nın doğrudan rolleri vardır. CDK7, CDK8, CDK9, CDK10 ve CDK11'1n DNA sentezi ve transkripsiyon düzenlemesinde ve CDK5'in postmitotik fonksiyonları mevcuttur [4].

CDK4-SiklinD, CDK6-SiklinD ve CDK3-SiklinC kompleksleri, pRb (retinoblastoma proteini) fosforile ederek G0 / G1 geçişini (hareketsiz hücrelerde) ve G1'in erken evrelerini düzenler. CDK2SiklinE kompleksleri, mitojenik olarak bağımsız olan pRb'nin fosforilasyonunu tamamlar ve G1 / S geçişinde, DNA replikasyonunda rol oynar. CDK2 daha sonra S fazında ilerleme sırasında Siklin A ile birleşir. CDK1, Siklin A ve Siklin B'ye sırayla bağlanarak S / G2 ve G2 / M geçişlerine katılır. CAK (CDK aktive edici kinaz), tüm hücre döngüsü CDK'larını fosforile eder. CDK7, hem aktivasyon segmentinde ( $\mathrm{T}$ döngü) rol oynar hem genel transkripsiyon faktörünün bir bileşenidir. CDK8'in 
transkripsiyon döngüsünün birçok aşamasında gen aktivitesini teşvik eder. CDK9 RNA Polimeraz II'nin en büyük alt birim C-terminali alanını fosforile ederek işlev görür. CDK10 / 11 nörogenezde nöron apoptotik sürecinin negatif düzenlenmesinde ve beyin, göz, karaciğer, ve peritoneal bölgede histon fosforilasyonuna katılır. CDK10 ve CDK11 mitozda rol oynayabilir, ancak bunların aktif olduğu fonksiyonel bölgeler iyi anlaşılmamıştır. Son olarak, G1'e giriş için Siklin F gerekir ve Siklin G, G2 / M geçişi sırasında DNA hasar yanıtında rol oynar (Şekil 3) [6].

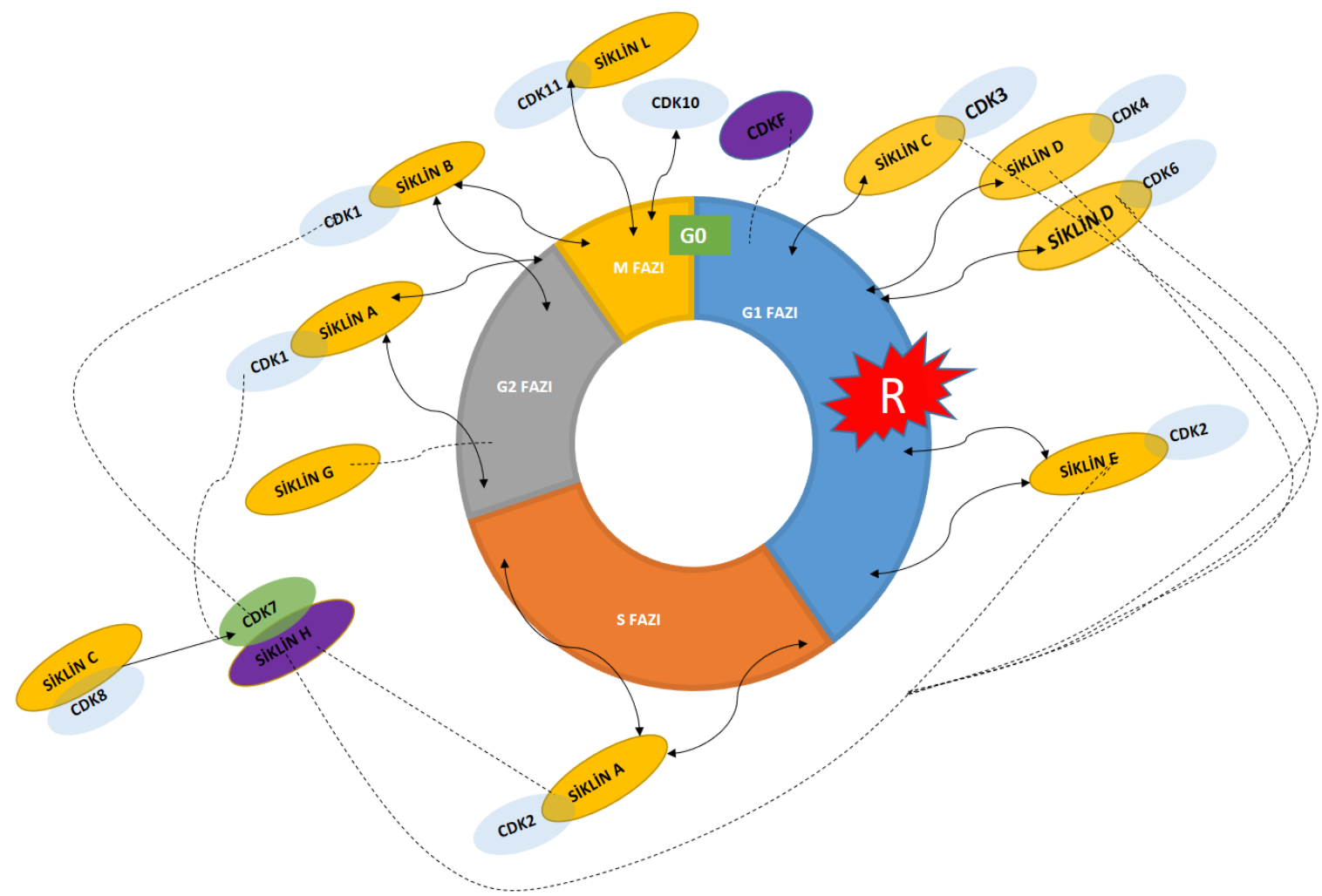

Şekil 3. Hücre döngüsünde CDK'ların rolü

G1 fazının erken evrelerinde ilk gerçekleşen olaylardan biri, sinyal iletim yolunun son noktası olan D-tipi siklinlerin sentezi olduğunu bilinmektedir [5]. D tipi siklinlerin varlığı, birbiriyle yakından ilişkili iki kinaz olan CDK4 ve CDK6'ya katalitik aktivite kazandırır. Aktif Siklin D-CDK4 / 6 kompleksi hücrelerin R noktasından ve erken G1 fazından geçmesine yardımcı olur. Bu, iki bağımsız mekanizma ile gerçekleşir. İlk olarak, CDK4 / 6-Siklin D, Siklin E1'in sentezi için gerekli E2F (ökaryotlarda transkripsiyon faktörleri ailesini kodlayan gen) transkripsiyon faktörlerinin aktivasyonu ile sonuçlanan pRb'yi fosforile eder. İkincisi, Siklin D-CDK4 / 6 kompleksleri, birincil rolü Siklin ECDK2 aktivitesini inhibe etmek olan hücre döngüsü inhibitörleri ailesini, siklin bağımlı kinaz inhibitör proteinlerini yani CIP / KIP ailesini bağlar. Heterotrimerik Siklin D-CDK4 / 6-CIP / KIP komplekslerinin oluşumu, bu inhibitörlerin uzaklaştırılmasıyla Siklin E-CDK2 komplekslerinin inaktive edilmesini önleyerek G1 ilerlemesine katkıda bulunur (Şekil 3) [8]. 
D-tipi siklinler (D1, D2 ve D3), hücre dışı sinyal yollarının ana hedefleridir. Mitojenik sinyaller D-tipi siklin ekspresyonu sonucu CDK4 / 6'nın hücre içinde konsantrasyonunun artmasına neden olur [7] . G1 sirasında D-tipi siklinlerin spesifik antikorlarla bloke edilmesi hücrelerin S fazına girmesini önler . Benzer şekilde, D-tipi siklinlerin aşırı ekspresyonu in vitro olarak G1 / S geçişini hızlandırır [9].

\section{Hücre Döngüsünde CDK İlişkili İnhibitör Proteinler ve İşlevleri}

pRb, hücre döngüsünde hücreyi G1'den S fazına ilerletmek için gerekli olan sayısız genin ekspresyonunu düzenlemesine izin verir. pRb'nin proteinleri bağlama ve düzenleme kabiliyeti büyük ölçüde fosforilasyon durumu ile belirlenir. pRb hipofosforile olduğunda, E2F dahil olmak üzere bağlanma bölgesiyle ilişki kurabilir. Bu bağlanma E2F'nin hedef genlerini aktive etmesini önler. E2F’ye bağlı pRb, transkripsiyonu aktif olarak bastırır. pRb' nin fosforilasyonu, E2F'nin salınması ve daha sonra DNA sentezi için gerekli genlerin aktivasyonu ile sonuçlanır. G1 Siklin / CDK komplekslerinin bazıları fosforilasyon için $\mathrm{pRb}$ proteinini hedefler [10].

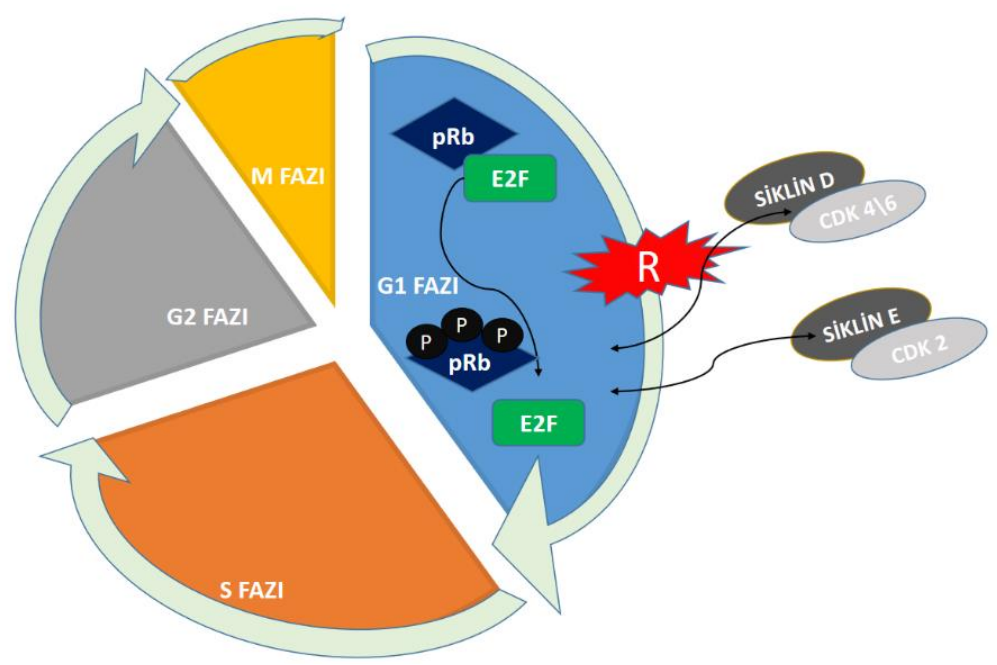

Şekil 4. Rb’nın hücre döngüsündeki rolü

$\mathrm{pRb}$ fosforilasyonu, tek bir kinaz tarafından değil, her biri bir pRb'nin fosforilasyon bölgelerinin bir alt grubunu fosforile eden bir Siklin/CDK kombinasyonuyla gerçekleşir [11].

Hücre döngüsünde kontrol basamağı olan R noktasından geçiş Rb protein ailesi, pRb, p107 ve p130 tarafından düzenlenmektedir [12]. G1'in başlangıcında, Rb proteinleri, çok sayıda proteini bağlamalarına izin veren aktif, fosforlanmamış bir durumda bulunur. pRb'ye bağlanma, fizyolojik hedeflerinden sekestrasyon yoluyla veya inaktif kompleksler oluşturarak fonksiyonel inaktivasyonuna neden olur [13]. G1 sırasında, Rb proteinleri, D-tipi sikline-bağlı CDK4 / 6 ve E-tipi sikline bağlı CDK2'nin ve diğer CDK'ların aracılık ettiği ardışı fosforilasyon ile etkisiz hale getirir (Şekil 4). Rb proteinlerinin inaktivasyonu, G2 / M veya G0 sırasında inaktif olarak muhafaza edilen hücre döngüsü ilerlemesi için gerekli proteinlerin birlikte salınması ve aktivasyonu ile sonuçlanır. Dolayısıyla, Rb'nin fosforilasyon durumu ile hücresel replikasyon arasında güçlü bağlantı vardır [14]. 


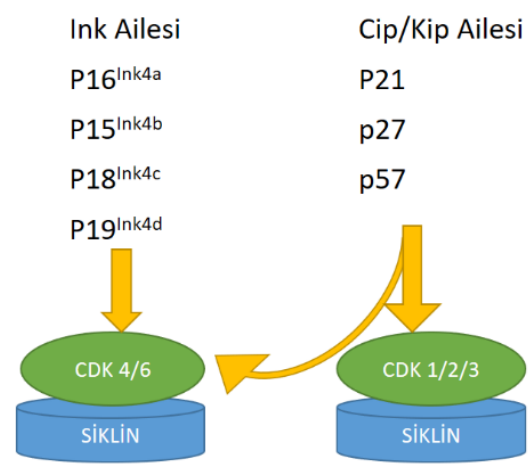

Şekil 5. CDK4 / 6 ilişsili inhibitör protein aileleri

CDK'lar iki polipeptit inhibitörü ailesi tarafından inhibisyona tabidir : CIP / KIP ve INK4 (Şekil 5). Bu inhibitörler, elverişsiz koşullar altında hücre döngüsü geçişini durdurur. Üç proteinden oluşan CIP / KIP ailesi, CDK'larla etkileşen ve inhibe eden hücre döngüsü düzenleyicileri olarak tanımlanır. CIP / KIP protein ailesi ayrica apoptoz, sitoskeletal yeniden düzenleme ve transkripsiyonel düzenlemeye kat1lir [15].

CIP / KIP ailesi üyeleri, p21 ${ }^{\text {IP1 }}$, p27 Kip1 ve p57 Kip2 , CDK-Siklin komplekslerine bağlanarak onları inhibe ederler (Şekil 5). INK4 ve CIP / KIP proteinleri, tümör baskılayıcı aktivite sergiler ve sıklıkla insan tümörlerinde farklı mekanizmalarla inaktive edilir [16].

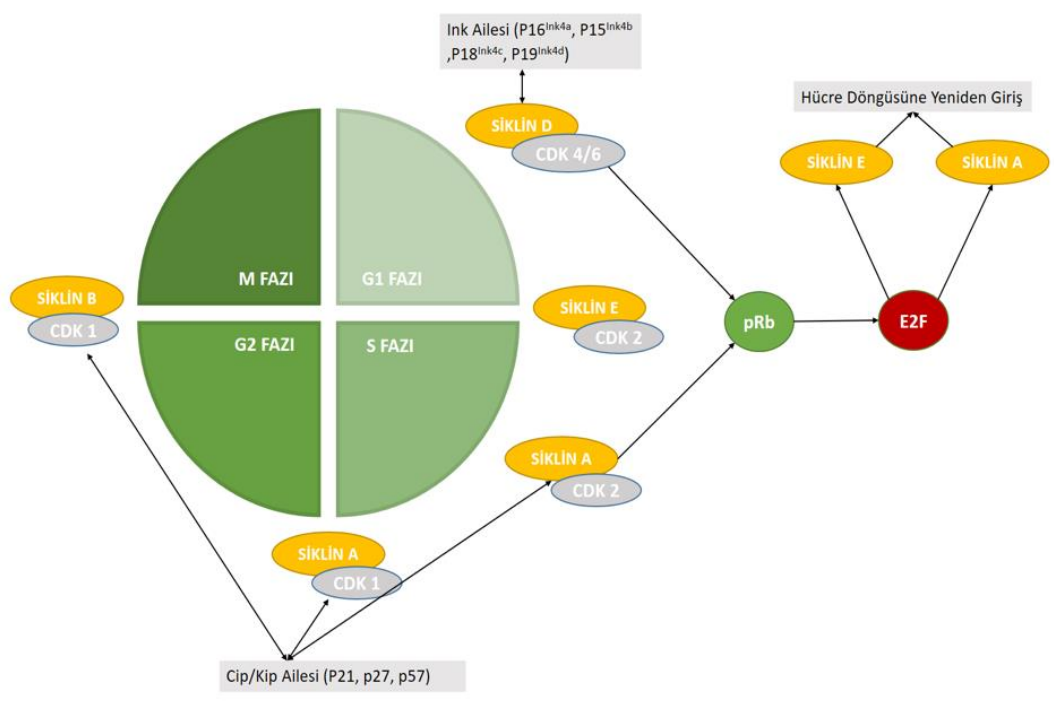

Şekil 6. CDK4 / 6 ilişkili intibitör proteinlerin hücre döngüsündeki rolü

CIP / KIP ailesinin CKI'leri hem CDK2'ye hem de CDK4 / 6'ya bağlanır ve kinaz aktivitelerini modüle eder (Şekil 5). Hareketsiz hücrelerde, CIP / KIP CKI'leri CDK2'ye bağlanır ve aktivitesini inhibe ederek hücre döngüsü durmasına neden olur (Şekil 6). Döngüsel hücrelerde, CIP / KIP ailesinin 
CKI'leri CDK2/Siklin E kompleksinden ayr1lır ve bunun yerine CDK4 / 6'ya bağlanarak CDK2'nin ve CDK4 / 6'nın daha fazla aktivasyonuna neden olarak hücreye bağlanmasına neden olur [17].

\section{Kanser Oluşum Mekanizmasında CDK 4/6 Rolü}

CDK4 / 6-Siklin D / INK4 / Rb yolu, insan kanserlerinde en sık mutasyona uğramış yollardan biridir. Sağlıklı bir hücrede döngü şu şekilde ilerler; Aktif CDK4 / 6 Rb'u fosforiller ve pRb inaktif hale gelerek, hücre siklusunı devam ettirir. $M$ döneminde hücresel fosfatazlar ile pRb'de fosfat grupları çıkarılır. Böylece yeniden hipofosforile şekil ortaya çıkar ve $\mathrm{pRb}$ yeniden aktifleşerek döngüyü durdurur (Şekil 7). Kanser hücrelerinde G1 progresyonu ve S fazı başlangıcının kontrolü bozulur. CDK4 / 6 aktivitesinin ve D-tipi siklinlerin aşırı ifadesi pRb'de mutasyon, delesyon, direkt inaktivasyon veya p16'nın çok fazla eksprese olması bile siklusta supresör etki yapmaz ve hücre proliferasyonu devam eder. Kontrolsüz proliferasyon sonucunda kanser hücresi gelişimi ortaya çıkar (Şekil 8) [18].

\section{Çoğalmayan Hücre}
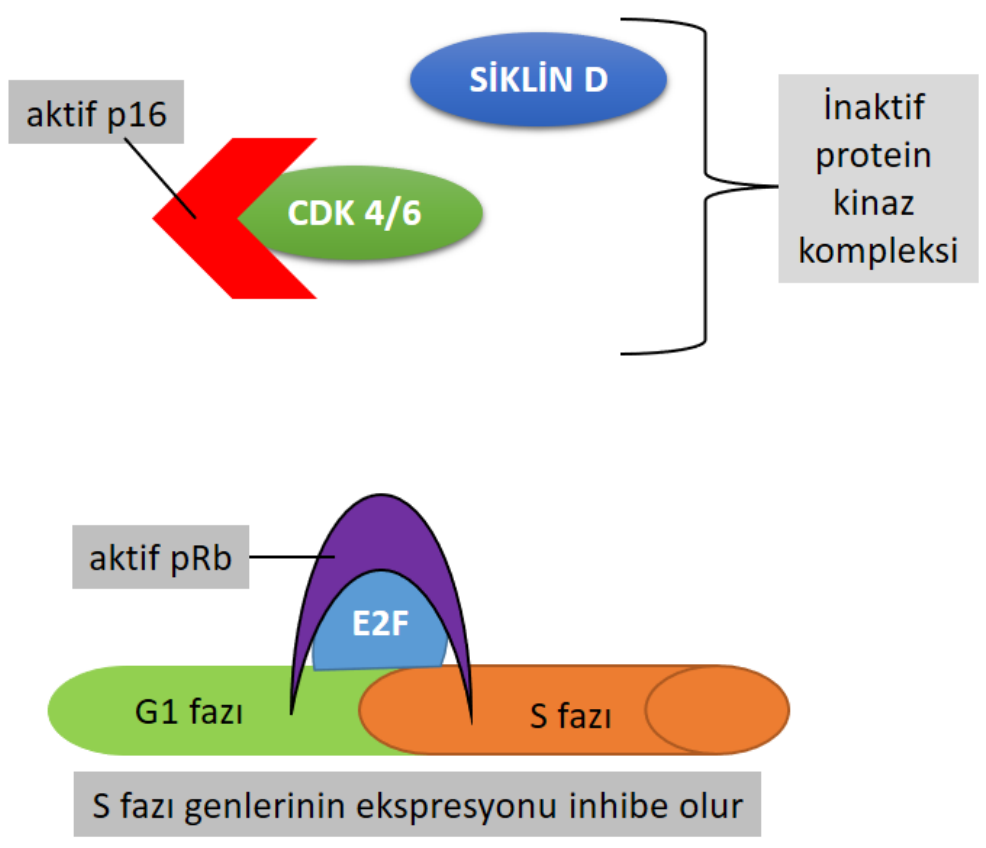

Şekil 7. Kontrolsüz çoğalmayan hücrenin mekanizması

CDK4 çok çeşitli tümörlerde ve tümör hücre dizilerinde çoğalır ve aşırı eksprese edilir [19]. Bazıları, esas olarak gliomlar [20], sarkomlar [21], meme tümörleri [19] ve rahim serviksindeki karsinomlar [22] , CDK6 geni, yass1 epitel hücreli karsinomlar ve gliomlar [23] ve lenfoid tümörler [24] dahil olmak üzere belirli tipte malignitelerde çoğalır. Kromozomal translokasyonlar ayrıca bazı lenfoid tümörlerde yüksek CDK6 ekspresyon seviyelerini de açıklar. 


\section{Kontrolsuz Çoğalan Hücre}

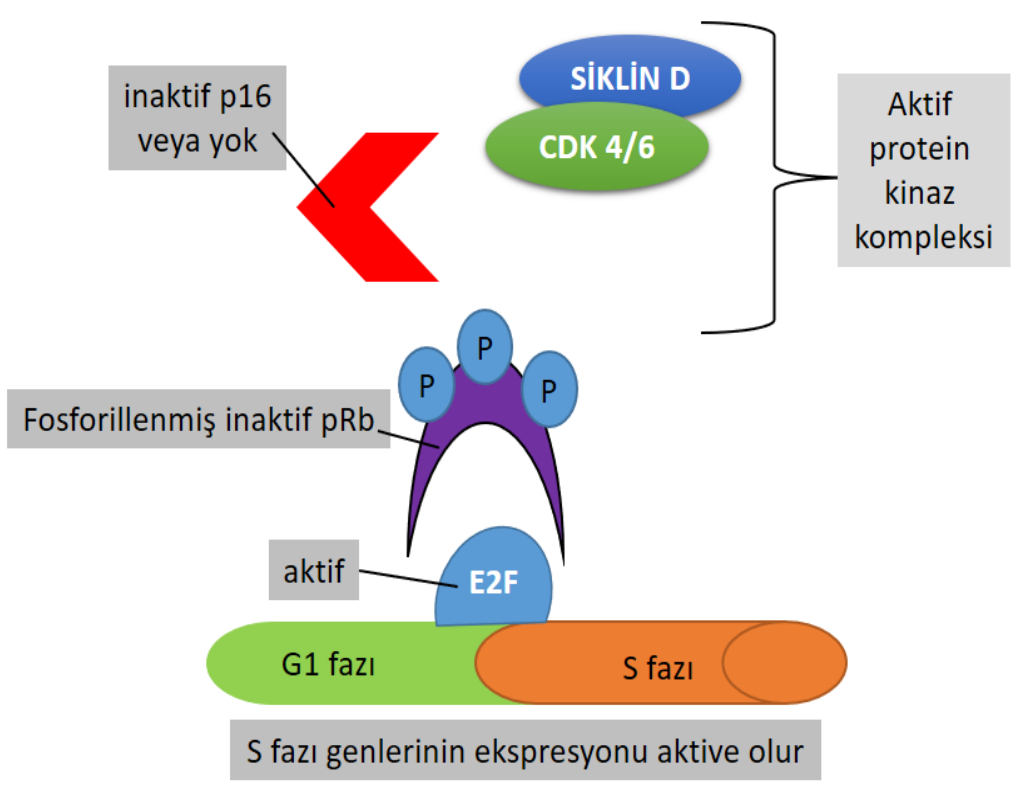

Şekil 8. Kontrolsüz çoğalan hücrenin mekanizması

\section{Kanser tedavisinde CDK4 / 6 inhibitörleri}

Üç özellik CDK inhibitörlerini potansiyel antitümör ajanları olarak çekici kılar. Birincisi, G1 veya G2 / M deki hücreleri durdurarak güçlü antiproliferatif ajanlardır (Şekil 9). İkincisi apoptozu tek başlarına veya diğer tedavilerle kombinasyon halinde tetiklerler. Üçüncüsü, bazı durumlarda, CDK'ların inhibisyonu hücre farklılaşmasına katkıda bulunur. Tanımlanan ilk CDK inhibitörleri, nispeten seçici olmadıkları ve preklinik çalışmalara dayalı olarak birçok teorik hedef dışı etkiye sahip oldukları için "pan-inhibitörler" olarak tanımlanabilir [25, 26]. İki ana nedenden dolayı, pan-inhibitörlerinin çoğu faz II denemelerinin ötesine geçmemiştir. İlk olarak, monoterapi olarak sınırlı klinik aktivite göstermiştir [25]. İkinci olarak, muhtemelen hedef dışı etkileşimlerden kaynaklanan ciddi toksisite ile ilişkilendirilmiştir. [27].

CDK inhibitörleri, belirli bir CDK'nın hücresel süreçteki rolünü göstermek için hücre biyolojisinde farmakolojik araçlar olarak kullanıldığında, seçicilik önemli bir konudur. Bunun aksine, mutlak seçicilik, çoklu yolların düzensiz olduğu karmaşık bozuklukları iyileştirmek için en iyi yaklaşım olmayabilir. Aslında, tek bir etkiden ziyade etki kombinasyonları daha iyi terapötik maddeler sağlayabilir. Hedef aralıklarını bilmek, hem istenen farmakolojik etkiyi elde etmek için vurulması gereken hedefler dizisi hem de inhibisyonu istenmeyen enzimler hakkında bilgi sağlayarak, iyileştirilmiş klinik etkinliğe sahip ajanların geliştirilmesine yardımcı olacaktır. İyi ve kötü hedeflerin belirlenmesi, toksik yan etkilerin önlenmesine yardımcı olabilir [28]. 


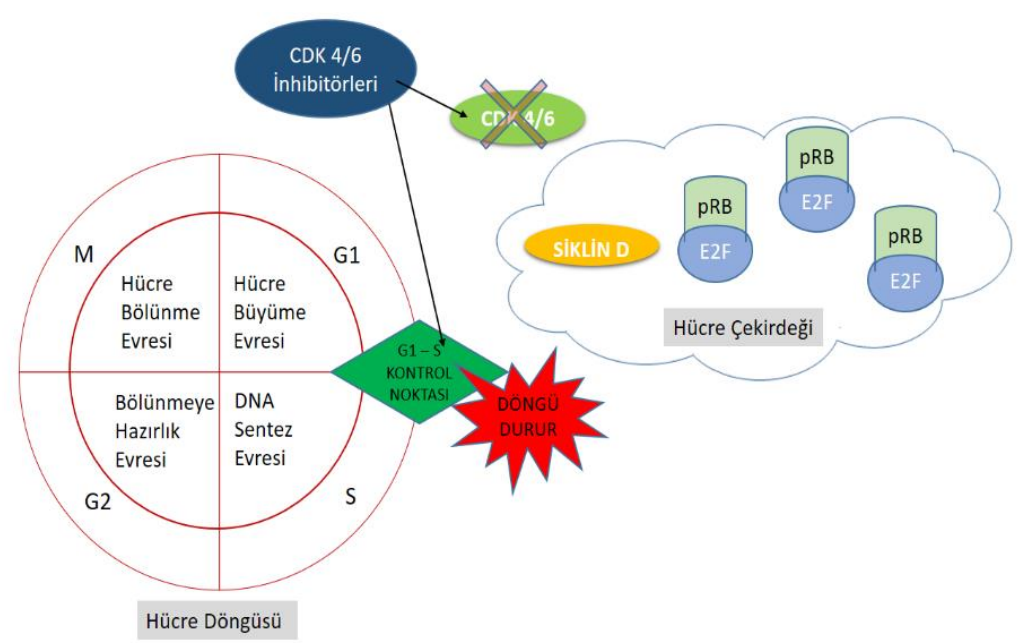

Şekil 9. CDK4 / 6 inhibitörlerinin hücre döngüsündeki rolü

Çoğu kanser hücresi fonksiyonel Rb'yi korur ve bunun yerine CDK4 / 6 kinaz aktivitesini arttırır. CDK4 / 6 kinaz aktivitesinin ablasyonu, siklin D’ye bağlı tümörlerde tümör büyümesinin tamamen inhibe edilmesine neden olduğu gösterilmiştir. Ayrıca, sağlıklı hücrelerin, CDK1 yokluğunda zarar gördüğü ancak CDK4 / 6'nın yokluğunun üstesinden geldiği gösterilmiştir [29].

ER (östrojen reseptörü) pozitif / HER2 (insan epidermal büyüme faktör reseptörü 2) negatif en yaygın meme kanseri alt tipidir ve ET (endokrin tedavisi), bu kanser tedavisinin terapötik omurgası olmaya devam etmektedir. Antiöstrojen tedavileri başlangıçta genellikle etkili olsa da, ER pozitif hastalarının yaklaşık \%50'si yaşamları boyunca ET’ye direnç geliştirir ve sonuçta hastalığın tekrarlamasına ve sınırlı klinik faydaya yol açar [30].

CDK4/6 inhibitörlerinin kullanımı artık ER pozitif / HER2 negatif meme kanserlerinin bakımına entegre edilmiş olup [31] ET'ye eklenmesi, tek başına antiöstrojenlere kıyasla ER pozitif ilerlemiş meme kanserli hastaların sonuçlarını önemli ölçüde iyileştirmiştir [32].

Hücre proliferasyonunu düzenlemede CDK4 / 6 aktivitesinin önemi ve bu yolağın kanserde aktive olduğu bilinen mekanizmalar nedeniyle, CDK4 / 6 inhibitörlerinin seçici inhibisyonu çekici bir terapötik strateji olarak ortaya çıkmıştır. Tüm bu kanıtlar birlikte ele alındığında seçici bir CDK4 / 6 inhibitörünün, seçici olmayan $\mathrm{CDK}$ inhibitörlerden daha geniş bir terapötik pencereye sahip olabileceğini gösterir [33].

\section{CDK4 / 6 İnhibitörlerinin Etki Mekanizması}

CDK4 / 6 inhibitörlerinin etki mekanizmasının mevcut bilgisi temel olarak palbosiklib ile yapılan preklinik çalışmalardan gelmektedir. CDK4 / 6 proteinin N ve C terminal lobları ATP bağlayıcı cep içerir. CDK inhibitörleri; temel olarak hidrofobik etkileşimler ve hidrojen bağları yoluyla bağlanma için ATP ile rekabet edebilmelerini sağlayan düşük moleküler ağırlıklı hidrofobik heterosikliklerdendir. RB ve ilgili proteinlerin fosforilasyonunu bloke eder ve S-faz siklinleri ve mitotik düzenleyici genleri inhibe 
eder. Nükleotid biyosentezi ve DNA replikasyonunu baskılayarak G1 / S hücre döngüsünü kuvvetle indükler. $\mathrm{Rb}$ pozitif meme karsinomlarında $\mathrm{DNA}$ ‘ya timidin eklemesini engellediği de bildirilmiştir [15].

Palbosiklib, pan- CDK inhibitörlerinin aksine ATP bağlanma cebine sıkıca oturur. Bu, palbosiklib'in hedefi ile daha büyük bir bağlanma arayüzüne sahip olmasıyla sonuçlanır, etkinliği arttırır [34].

\section{Seçici CDK4 / 6 İnhibitörleri}

Pablosiklib (Şekil 10); PD 0332991 koduyla ER pozitif / HER2 negatif meme kanseri tedavisi için 2013 Nisan ayında FDA onayı almıştır. Palbosiklib CDK4 / 6 için seçicidir ve diğer otuz altı protein kinaza karşı etkinliği yoktur veya çok azdır. Rb'yi silmiş meme kanseri hücre hatlarına karşı hiçbir aktivite göstermez. Faz II çalışmasında, palbosiklib plus letrozol ile tedavi, sadece letrozole kıyasla hastalık ilerlemesi riskini \% 51 azaltmıştır. Kombinasyon halinde, kemoterapi ve iyonlaştırıcı radyasyonla klinikte kullanılmaya başlanmışır. Östrojen reseptörüne edinilmiş tamoksifen direncini yeniden hassaslaştırır [15].<smiles>CC(=O)c1c(C)c2cnc(Nc3ccc(N4CCNCC4)cn3)nc2n(C2CCCC2)c1=O</smiles>

Şekil 10. Pablosiklib yapısı

Ribosiklib (Şekil 11); LEE011 koduyla ER pozitif / HER2 negatif meme kanseri tedavisi için 2017 Mart ayında FDA onayı almıştır. Manto hücreli lenfoma, liposarkom, melanom akciğer kanseri pankreas kanseri tedavisi için faz çalışmaları devam etmektedir. Ribosiklib ve 3-fosfoinositid bağımlı protein kinaz 1 (PDK1) inhibitörü GSK2334470'in kombinasyonu, meme kanseri hücre hatlarında proliferasyonu kuvvetle bastırdığı gözlenmiştir. Akciğer karsinomu hücre hatları ve primer tümör örneklerinde, ribosiklib, CDK4 / 6'ya karşı, palbosiklib'den daha seçici bulunmuştur [35]. 
<smiles>CN(C)C(=O)c1cc2cnc(Nc3ccc(N4CCNCC4)cn3)nc2n1C1CCCC1</smiles>

Şekil 11. Ribosiklib yapısı

Abemasiklib (Şekil 12); LY2835219 koduyla ER pozitif / HER2 negatif meme kanseri tedavisi için 2018 Şubat ayında FDA onayı almıştır. Abemasiklib CDK4'e karşı CDK6'ya göre 14 kat daha etkili olduğu bildirilmiştir.

Palbosiklib ve ribosiklibe kıyasla 5 kat daha aktiftir. Diğer CDK4 / 6 inhibitörlerinden farkı kan beyin bariyerini geçebilmesidir. Abemasiklibin LogP değeri ribosiklib ve palbosiklibin yaklaşık 2 katı bu da ATP yarığına bağlanma kolaylığı sağlamaktadır [36].

Lys43 ile oluşturduğu hidrojen bağı abemasiklibi CDK4 / 6 ya karşı daha az seçici yapar ve bunun sonucunda CDK 9 inhibisyonu gerçekleşir [37].<smiles>CCN1CCN(c2ccc(Nc3ncc(F)c(-c4cc(F)c5nc(C)n(C(C)C)c5c4)n3)nc2)CC1</smiles>

Şekil 12. Abemasiklib yapısı

Trilasiklib (Şekil 13); üçlü negatif meme kanseri hastaları için gemsitabin ve karboplatin ile kombinasyon halinde, faz III çalışlarını bitirmiş en yeni CDK4 / 6 inhibitörüdür [38]. Diğer 
inhibitörlerden farkı reseptöre bağlanırken ATP yarışmalı değildir [39]. G1T2812 koduyla 2021 Şubat ayında FDA onayı almıştır [40].

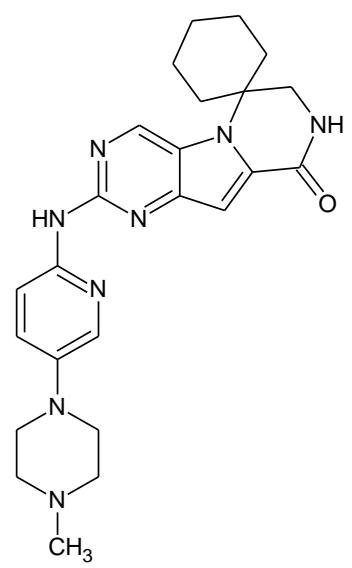

Şekil 13. Trilasiklib Yapıs1

\section{CDK4 / 6 İnhibitörlerinin Terapideki Yeri}

ER pozitif meme kanseri tedavisi için birçok endokrin tedavisi mevcuttur, ancak klinikte çoğu hastada başarısız sonuçlanmıştır. CDK4 / 6 inhibisyonu, endokrin terapisinde direncin üstesinden gelmek için önemli bir mekanizmadır. Palbosiklib, meme kanserli hastalarda tek bir ajan olarak çalışılmış ancak klinikte yanıt oranları (toplam popülasyonda \% 5) oldukça düşük bulunmuştur. İlk klinik çalışmalardan ümit verici sonuçlar palbosiklib'in, endokrin tedavisi ile kombinasyon halinde araştırılmasına yol açmıştır [41].

CDK4 / 6 inhibitörlerinin biyolojik fonksiyonunu sınırlayan etmen antitümör etkilerinin, aktif bir $\mathrm{Rb}$ proteininin varlığına bağlı olmasıdır. Palbosiklib, letrozol ile kombinasyon halinde, ER pozitif / HER2 negatif ileri meme kanserli hastalar için FDA'dan hızlandırılmış onay almıştır [42].

\section{SONUÇ VE TARTIŞMA}

Kanserli hücre döngüsünün düzensizliğii, kanser hücrelerinde ilaç ve endokrin tedavilerine karş1 direnç kazanılması terapötik olarak seçici hedefe odaklanılmasını ve yeni tedavi yaklaşımlarını zorunlu hale getirmiştir. Hücre döngüsü elemanlarından biri olan CDK'lara baktığımızda kanser tedavisinde seçici olarak hedefe odaklanabilinecek kinaz ailesindendir. Tüm CDK'ların inhibisyonu ile yapılan klinik çalışmalar sonucunda gözlemlenen istenmeyen etkiler, yine seçici bir hedefe odaklanılmasının önemini bir kez daha vurgulamıştır. Hücre döngüsünün kontrol noktasında önemli görev üstlenen CDK4 / 6'nın kanserli hücrelerde hiperaktivasyonu gözlenmektedir. Kanser hücresinde mitoz kontrolsüzlügüne neden olan CDK4 / 6'nın aşırı aktivasyonun keşfiyle beraber, CDK4 / 6 inhibitörleri yeni teröpatik hedef haline gelmiştir. Hücre mitoza girmeden, döngüyü durdurmayı hedefleyen yaklaşım CDK4 / 6'yı inhibe etmektir. Klinik çalışmalarda; seçici olarak CDK4 / 6'yı inhibitörlerinin, pan-CDK inhibitörlerine 
kıyasla istenmeyen etkileri azalttığı ve sağlıklı hücreleri de koruduğu gösterilmiştir. CDK4 / 6 aktivitesinin inhibisyonu bilhassa meme kanserinde umut verici bir terapötik yaklaşımdır.

\section{YAZAR KATKILARI}

Kavram: G.A., T.Ö.; Tasarım: G.A., A.B.Ö.; Denetim: G.A., T.Ö., A.B.Ö.; Kaynaklar: T.̈̈.; Malzemeler: G.A.; Veri toplama ve/veya işleme: G.A.; Analiz ve /veya yorumlama: G.A.; Literatür taraması: G.A.; Makalenin yazılması: G.A., A.B.Ö.; Kritik inceleme: A.B.Ö.; Diğer: -

\section{ÇIKAR ÇATIŞMASI BEYANI}

Yazarlar bu makale için gerçek, potansiyel veya algılanan çıkar çatışması olmadığını beyan ederler.

\section{KAYNAKLAR}

1. Reece, J. B., Urry, L. A., Cain, M. L., Wasserman, S. A., Minorsky, P. V., Jackson, R. B. (2014). Campbell biology, Boston: Pearson, p.1309.

2. Hochegger, H., Takeda, S., Hunt, T. (2008). Cyclin-dependent kinases and cell-cycle transitions: does one fit all?. Nature Reviews Molecular Cell Biology, 9(11), 910-916. [CrossRef]

3. Shapiro, G. I. (2006). Cyclin-dependent kinase pathways as targets for cancer treatment. Journal of Clinical Oncology, 24(11), 1770-1783.

4. DiPippo, A. J., Patel, N. K., Barnett, C. M. (2016). Cyclin- dependent kinase inhibitors for the treatment of breast cancer: past, present, and future. Pharmacotherapy: The Journal of Human Pharmacology and Drug Therapy, 36(6), 652-667. [CrossRef]

5. Pardee, A. B. (1974). A restriction point for control of normal animal cell proliferation. Proceedings of the National Academy of Sciences, 71(4), 1286-1290. [CrossRef]

6. Malumbres, M., Barbacid, M. (2005). Mammalian cyclin-dependent kinases. Trends in Biochemical Sciences, 30(11), 630-641. [CrossRef]

7. Sherr, C. J. (1996). Cancer cell cycles. Science, 274(5293), 1672-1677. [CrossRef]

8. Sherr, C. J., Roberts, J. M. (1999). CDK inhibitors: positive and negative regulators of G1-phase progression. Genes \& Development, 13(12), 1501-1512. [CrossRef]

9. Baldin, V., Lukas, J., Marcote, M. J., Pagano, M., Draetta, G. (1993). Cyclin D1 is a nuclear protein required for cell cycle progression in G1. Genes \& Development, 7(5), 812-821. [CrossRef] 
10. Kasten, M. M., Giordano, A. (1998). pRb and the cdks in apoptosis and the cell cycle. Cell Death \& Differentiation, 5(2), 132-140. [CrossRef]

11. Mittnacht, S. (1998). Control of pRB phosphorylation. Current Opinion in Genetics \& Development, 8(1), 21-27. [CrossRef]

12. Sherr, C. J. (1994). G1 phase progression: cycling on cue. Cell, 79(4), 551-555. [CrossRef]

13. Harbour, J. W., Dean, D. C. (2000). Chromatin remodeling and Rb activity. Current Opinion in Cell Biology, 12(6), 685-689. [CrossRef]

14. Bartek, J., Lukas, J. (2001). Pathways governing G1/S transition and their response to DNA damage. FEBS Letters, 490(3), 117-122. [CrossRef]

15. Roskoski Jr, R. (2016). Cyclin-dependent protein kinase inhibitors including palbociclib as anticancer drugs. Pharmacological Research, 107, 249-275. [CrossRef]

16. Ruas, M. (1998). The p16/CDKN2A tumor suppressor and its relatives. Biochimica et Boophysica Acta, 1378, 115-177. [CrossRef]

17. Chim, C. S., Liang, R., Fung, T. K., Kwong, Y. L. (2005). Infrequent epigenetic dysregulation of CIP/KIP family of cyclin-dependent kinase inhibitors in multiple myeloma. Leukemia, 19(12), 2352-2355. [CrossRef]

18. Ortega, S., Malumbres, M., Barbacid, M. (2002). Cyclin D-dependent kinases, INK4 inhibitors and cancer. Biochimica et Biophysica Acta (BBA)-Reviews on Cancer, 1602(1), 73-87. [CrossRef]

19. An, H. X., Beckmann, M. W., Reifenberger, G., Bender, H. G., Niederacher, D. (1999). Gene amplification and overexpression of CDK4 in sporadic breast carcinomas is associated with high tumor cell proliferation. The American Journal of Pathology, 154(1), 113-118. [CrossRef]

20. He, J., Allen, J. R., Collins, V. P., Allalunis-Turner, M. J., Godbout, R., Day, R. S., James, C. D. (1994). CDK4 amplification is an alternative mechanism to p16 gene homozygous deletion in glioma cell lines. Cancer Research, 54(22), 5804-5807.

21. Wei, G., Lonardo, F., Ueda, T., Kim, T., Huvos, A. G., Healey, J. H., Ladanyi, M. (1999). CDK4 gene amplification in osteosarcoma: reciprocal relationship with INK4A gene alterations and mapping of 12q13 amplicons. International Journal of Cancer, 80(2), 199-204. [CrossRef]

22. Cheung, T. H., Yu, M. M. Y., Lo, K. W. K., Yim, S. F., Chung, T. K. H., Wong, Y. F. (2001). Alteration of cyclin D1 and CDK4 gene in carcinoma of uterine cervix. Cancer Letters, 166(2), 199-206. [CrossRef]

23. Costello, J. F., Plass, C., Arap, W., Chapman, V. M., Held, W. A., Berger, M. S., Huang H-J. S., Cavenee, W. K. (1997). Cyclin-dependent kinase 6 (CDK6) amplification in human gliomas identified using two-dimensional separation of genomic DNA. Cancer Research, 57(7), 12501254. [CrossRef] 
24. Chilosi, M., Doglioni, C., Yan, Z., Lestani, M., Menestrina, F., Sorio, C., Benedetti A., Vinante F., Pizzolo G., Inghirami, G. (1998). Differential expression of cyclin-dependent kinase 6 in cortical thymocytes and T-cell lymphoblastic lymphoma/leukemia. The American Journal of Pathology, 152(1), 209. [CrossRef]

25. Asghar, U., Witkiewicz, A. K., Turner, N. C., Knudsen, E. S. (2015). The history and future of targeting cyclin-dependent kinases in cancer therapy. Nature Reviews Drug Discovery, 14(2), 130-146. [CrossRef]

26. Cicenas, J., Kalyan, K., Sorokinas, A., Jatulyte, A., Valiunas, D., Kaupinis, A., Valius, M. (2014). Highlights of the latest advances in research on CDK inhibitors. Cancers, 6(4), 2224-2242. [CrossRef]

27. Rizzolio, F., Tuccinardi, T., Caligiuri, I., Lucchetti, C., Giordano, A. (2010). CDK inhibitors: from the bench to clinical trials. Current Drug Targets, 11(3), 279-290. [CrossRef]

28. Knockaert, M., Greengard, P., Meijer, L. (2002). Pharmacological inhibitors of cyclin-dependent kinases. Trends in Pharmacological Sciences, 23(9), 417-425. [CrossRef]

29. Hamilton, E., Infante, J. R. (2016). Targeting CDK4/6 in patients with cancer. Cancer Treatment Reviews, 45, 129-138. [CrossRef]

30. Razavi, P., Chang, M. T., Xu, G., Bandlamudi, C., Ross, D. S., Vasan, N., Cai, Y., Bielski, C. M., Donoghue, M. T. A., Jonsson, P., Penson, A., Shen, R., Pareja, F., Kundra, R., Middha, S., Cheng, M. L., Zehir, A., Kandoth, C., Patel, R., Huberman, K., Smyth, L. M., Jhaveri, K., Modi, S., Traina, T. A., Dang, C., Zhang, W., Weigelt, B., Li, B. T., Ladanyi, M., Hyman, D. M., Schultz, N., Robson, M. E., Hudis, C., Brogi, E., Viale, A., Norton, L., Dickler, M. N., Berger, M. F., Iacobuzio-Donahue, C. A., Chandarlapaty, S., Scaltriti, M., Reis-Filho, J. S., Solit, D. B., Taylor, B. S., Baselga, J. (2018). The genomic landscape of endocrine-resistant advanced breast cancers. Cancer Cell, 34(3), 427-438. [CrossRef]

31. Matutino, A., Amaro, C., Verma, S. (2018). CDK4/6 inhibitors in breast cancer: beyond hormone receptor-positive HER2-negative disease. Therapeutic Advances in Medical Oncology, 10, 1758835918818346. [CrossRef]

32. Roberto, M., Astone, A., Botticelli, A., Carbognin, L., Cassano, A., D’Auria, G., Fabbri, A., Fabi, A., Gamucci, T., Krasniqi, E., Minelli, M., Orlandi, A., Pantano, F., Paris, I., Pizzuti, L., Portarena, I., Salesi, N., Scagnoli, S., Scavina, P., Tonini, G., Vici, P., Marchetti, P. (2021). CDK4/6 inhibitor treatments in patients with hormone receptor positive, Her2 negative advanced breast cancer: potential molecular mechanisms, clinical implications and future perspectives. Cancers, 13(2), 332. [CrossRef]

33. Roberts, P. J., Bisi, J. E., Strum, J. C., Combest, A. J., Darr, D. B., Usary, J. E., Zamboni, W. C., Wong, K. K., Perou, C. M., Sharpless, N. E. (2012). Multiple roles of cyclin-dependent kinase 4/6 inhibitors in cancer therapy. Journal of the National Cancer Institute, 104(6), 476-487. [CrossRef]

34. Choi, Y. J., Anders, L. (2014). Signaling through cyclin D-dependent kinases. Oncogene, 33(15), 1890. [CrossRef] 
35. Tripathy, D., Bardia, A., Sellers, W. R. (2017). Ribociclib (LEE011): mechanism of action and clinical impact of this selective cyclin-dependent kinase 4/6 inhibitor in various solid tumors. Clinical Cancer Research, 23(13), 3251-3262. [CrossRef]

36. Kim, E. S. (2017). Abemaciclib: first global approval. Drugs, 77(18), 2063-2070. [CrossRef]

37. Patnaik, A., Rosen, L. S., Tolaney, S. M., Tolcher, A. W., Goldman, J. W., Gandhi, L., Papadopoulos, K. P., Beeram, M., Rasco, D. W., Hilton J. F., Nasir, A., Beckmann, R. P., Schade, A. E., Fulford, A. D., Nguyen, T. S., Martinez, R., Kulanthaivel, P., Li, L. Q., Frenzel, M., Cronier, D. M., Chan, E. M., Flaherty, K. T., Wen, P. Y. Shapiro, G. I. (2016). Efficacy and safety of abemaciclib, an inhibitor of CDK4 and CDK6, for patients with breast cancer, nonsmall cell lung cancer, and other solid tumors. Cancer Discovery, 6(7), 740-753. [CrossRef]

38. Lima, C. M. S. R., Roberts, P. J., Priego, V. M., Divers, S. G., Thomas, M. B., Boccia, R. V., Stabler, K., Andrews, E., Malik, R. K., Aljumaily, R., Hamm, J. T., Chiu, V. K., Richards, D.A., Nikolinakos, P., Hussein, M. A., Schuster, S. R., Hoyer, R. J., Shapiro, G., Dragnev, K. H., Owonikoko, T. K. (2017). Trilaciclib (G1T28): a cyclin dependent kinase 4/6 inhibitor, in combination with etoposide and carboplatin (EP) for extensive stage small cell lung cancer (ESSCLC)-phase 1b results. Journal of Clinical Oncology, 35(suppl), 8568. [CrossRef]

39. Tan, A. R., Wright, G. S., Thummala, A. R., Danso, M. A., Popovic, L., Pluard, T. J., Han, H. S., Vojnović, Ž., Vasev, N., Ma, L., Richards, D. A., Wilks, S. T., Milenković, D., Yang, Z., Antal, J. M., Morris, S. R., O'Shaughnessy, J. (2019). Trilaciclib plus chemotherapy versus chemotherapy alone in patients with metastatic triple-negative breast cancer: a multicentre, randomised, open-label, phase 2 trial. The Lancet Oncology, 20(11), 1587-1601. [CrossRef]

40. Drugs.com Web site (2000). Retrieved March 4, 2021, from https://www.drugs.com/history/cosela.html Erişim Tarihi: 24.04.2021

41. O'leary, B., Finn, R. S., Turner, N. C. (2016). Treating cancer with selective CDK4/6 inhibitors. Nature Reviews Clinical Oncology, 13(7), 417-430. [CrossRef]

42. Knudsen, E. S., Witkiewicz, A. K. (2017). The strange case of CDK4/6 inhibitors: mechanisms, resistance, and combination strategies. Trends in Cancer, 3(1), 39-55. [CrossRef] 